\title{
Records of five bryozoan species from offshore gas platforms rare for the Dutch North Sea
}

Esther D. Beukhof ${ }^{1,2,3^{*}}$, Joop W. P. Coolen ${ }^{2,3}$, Babeth E. van der Weide ${ }^{3}$, Joël Cuperus $^{3}$, Hans de Blauwe and Jerry Lust ${ }^{3,5}$

\begin{abstract}
This study reports on bryozoan species collected at three offshore gas platforms in the Dutch part of the North Sea. Four out of thirteen observed species are considered as rare in the Netherlands, whereas Cribrilina punctata is a new species for Dutch waters.
\end{abstract}

Keywords: Bryozoa, North Sea, Netherlands, Offshore, Gas platform, Cribrilina punctata, Arachnidium fibrosum, Electra monostachys, Scruparia ambigua, Scruparia chelata

\section{Introduction}

The Dutch continental shelf of the North Sea largely consists of sandy bottoms. Rocky substrates are only present on the Cleaver Bank (Schrieken et al. 2013), the Borkum Reef Grounds (Coolen et al. 2015) and the Texel Rough (personal observation J.W.P. Coolen). Furthermore, artificial hard substrates are formed by shipwrecks (Lengkeek et al. 2013a), wind farms (Lindeboom et al. 2011; Vanagt et al. 2013) and gas platforms (Van Buuren 1984; Van der Stap et al. 2015).

Bryozoa grow on various hard substrates such as rocks, shells, wood, and plastic material, but also on macroalgae and Hydrozoa (De Blauwe 2009). Previous observations of Bryozoa in the Netherlands concentrated on southern coastal areas (Faasse and De Blauwe 2004). Faasse et al. (2013) recently reviewed the list of known Dutch Bryozoa which now comprises a total of 58 marine and estuarine species. They excluded specimens found on beached material, but included fauna from several recent offshore surveys of the Cleaver Bank (Van Moorsel 2003), the Princess Amalia Wind Farm (PAWF;

\footnotetext{
*Correspondence: estb@aqua.dtu.dk

${ }^{1}$ Current address: Centre for Ocean Life, National Institute of Aquatic Resources (DTU Aqua), Technical University of Denmark, Jægersborg Allé 1, 2920 Charlottenlund, Denmark

2Wageningen University \& Research, Chair Group of Aquatic Ecology and Water Quality Management, PO Box 47, 6700 AA Wageningen, The Netherlands

Full list of author information is available at the end of the article
}

Vanagt et al. 2013) and a shipwreck on the sandy Dogger Bank (Schrieken et al. 2013).

This article reports on the finding of 13 bryozoan species on three offshore gas platform in the Dutch part of the North Sea. Of these species, Cribrilina punctata is new to the Dutch fauna, and four species are considered rare to the Dutch waters.

\section{Materials and methods}

The Bryozoa described here were observed during inventories of the fouling community of three stationary offshore gas platforms. The platforms differed in their distance from the Dutch shore, maximum depth and year of construction, and were sampled at different times during 2014 and 2015 (Table 1). Macrofauna samples were taken from the platform foundation by a commercial diver using a putty knife to detach the organisms and a surface supplied airlift sampler to collect them. In the airlift, all organisms were sieved over a $500 \mu \mathrm{m}$ mesh. Further details of the airlift sampler and collection methods are described in Coolen et al. (2015). Triplicate samples were taken at $5 \mathrm{~m}$ depth intervals between 0 and $25 \mathrm{~m}$ and from the scour protection rocks on the bottom. After collection samples were fixed in a $6 \%$ formalin solution buffered with $2 \mathrm{~g} \mathrm{~L}^{-1}$ borax. Following transport to the lab (between three and five days after collection) all organisms were conserved in $70 \%$ ethanol until sorted by major taxonomic units and identified. All 
Table 1 Three offshore gas platforms were visited during several inventories in 2014 and 2015. The platforms differed in their distance from shore, depth at the seabed and year of construction

\begin{tabular}{|c|c|c|c|c|c|}
\hline Platform & Location & $\begin{array}{l}\text { Distance from } \\
\text { shore }(\mathrm{km})\end{array}$ & $\begin{array}{l}\text { Maximum } \\
\text { depth }(m)\end{array}$ & Year of construction & Sampling date \\
\hline L10-G & $53^{\circ} 29^{\prime} \mathrm{N}, 4^{\circ} 11^{\prime} \mathrm{E}$ & 70 & 26 & 1984 & June 2014 \\
\hline L10-A & $53^{\circ} 24^{\prime} \mathrm{N}, 4^{\circ} 12^{\prime} \mathrm{E}$ & 48 & 27 & 1972 & $\begin{array}{l}\text { April and June 2014, } \\
\text { October } 2015\end{array}$ \\
\hline L15-A & $53^{\circ} 19^{\prime} \mathrm{N}, 4^{\circ} 49^{\prime} \mathrm{E}$ & 5 & 21 & 1992 & June 2014 \\
\hline
\end{tabular}

shells of Mytilus edulis, other biogenic hard substrates and the scour protection rocks were inspected for the presence of Bryozoa. Any detached colonies were identified as well.

For identification Hayward and Ryland (1998), Hayward and Ryland (1999) and De Blauwe (2009) were consulted. The World Register of Marine Species (WoRMS Editorial Board 2015) was used as a taxonomic standard. Specimens were observed using a Zeiss SteREO Discovery.V8 stereomicroscope. When a specimen was covered by a thin layer of organic material which impeded observing the zooids, it was immersed in bleach for half an hour, then rinsed and dried in order to reveal the calcified skeleton.

\section{Results}

In 35 samples, a total of 13 species of Bryozoa were observed (Table 2). In ten samples no Bryozoa were encountered. Here, the findings of four species rare to Dutch waters and one new species for the Netherlands are described in more detail.

Five young colonies of the cheilostomatous Cribrilina punctata were found on three scour protection rocks of

Table 2 Bryozoa species encountered on the platform legs and/or the scour protection rocks at the bottom of the platforms L10-G, L10-A and L15-A

\begin{tabular}{|c|c|c|c|c|}
\hline \multirow[b]{2}{*}{ Species } & \multicolumn{2}{|c|}{ Platform legs } & \multicolumn{2}{|c|}{ Scour protection rocks } \\
\hline & L10-G & L10-A & L10-G & L15-A \\
\hline Alcyonidioides mytili & $x$ & $x$ & & $x$ \\
\hline Arachnidium fibrosum ${ }^{a}$ & $x$ & $x$ & & $x$ \\
\hline Aspidelectra melolontha & & & $x$ & \\
\hline Callopora dumerilii & $x$ & $x$ & $x$ & \\
\hline Celleporella hyalina & $x$ & $x$ & & \\
\hline Conopeum reticulum & $x$ & $x$ & $x$ & $x$ \\
\hline Cribrilina punctata $^{a}$ & & & $x$ & \\
\hline Electra monostachys ${ }^{a}$ & & & $x$ & \\
\hline Electra pilosa & $x$ & $x$ & $x$ & $x$ \\
\hline Microporella ciliata & $x$ & & & \\
\hline Schizomavella linearis & $x$ & $x$ & & $x$ \\
\hline Scruparia ambigua & $x$ & $x$ & & \\
\hline Scruparia chelata ${ }^{a}$ & $x$ & $x$ & & \\
\hline
\end{tabular}

indicates species discussed in the article platform L10-G consisting of 10 to approximately 30 non-ovicellate zooids (Fig. 1). A sub-oral bar with acute median mucro and 3-6 oral spines were present.

The ctenostomatous Arachnidium fibrosum was encountered in two samples taken from the foundation of platform L10-G at $10 \mathrm{~m}$ depth. Both colonies were attached to Mytilus edulis. Another colony of A. fibrosum was observed on a scour protection rock collected at the bottom of platform L15-A. Zooids were arranged in rows, and the colonies were sometimes branched.

A colony of Electra monostachys comprising several dozens of zooids was found on one of the scour protection rocks from platform L10-G. De Blauwe (2009)

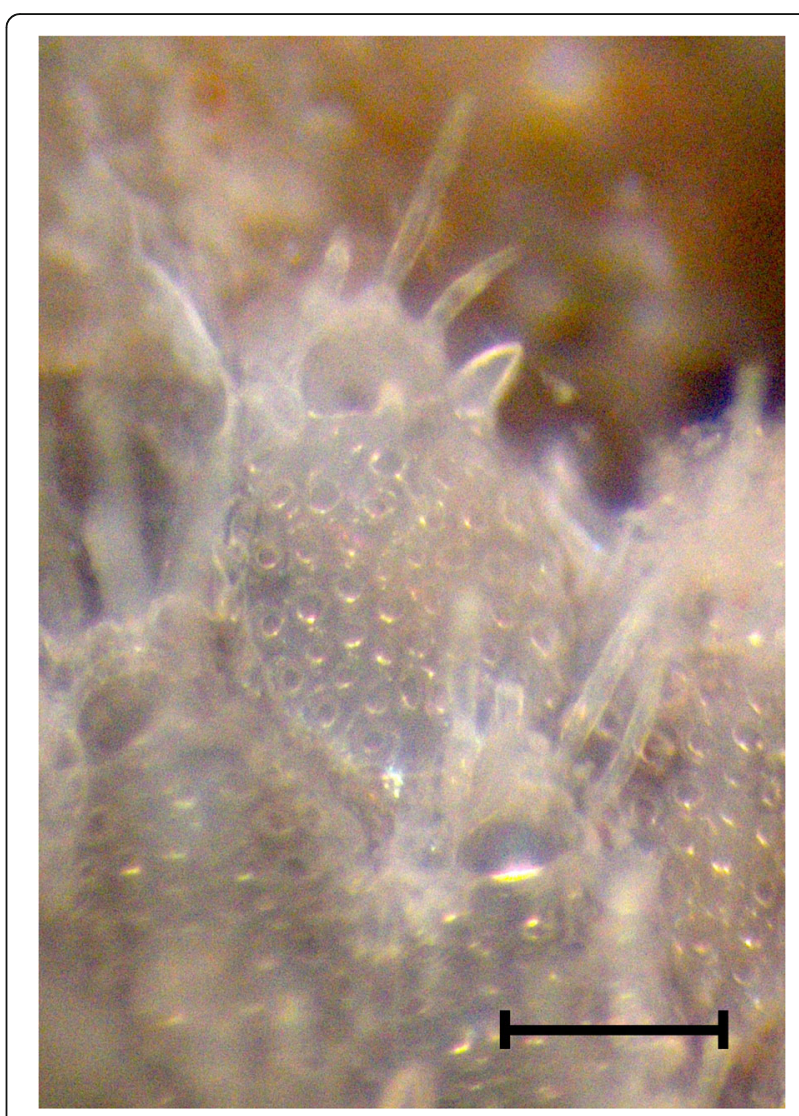

Fig. 1 Cribrilina punctata zooids as found on a scour protection rock at the bottom of the platform. Scale bar: $0.2 \mathrm{~mm}$ 
described a radiating crust as being characteristic for the species; this shape was also observed here. In addition to the relatively long proximal spine and pair of shorter distally located spines, almost all zooids still had their 4-6 pairs of shorter spines located around the frontal membrane.

Two members of the genus Scruparia were encountered. Scruparia ambigua was observed in one sample attached to M. edulis collected at $10 \mathrm{~m}$ depth at platform L10-G, but detached specimens were found as well. Several samples from platform L10-A taken between 5 and $15 \mathrm{~m}$ depth also contained a number of S. ambigua colonies. Scruparia chelata was observed at different depths $(5-25 \mathrm{~m})$ on platforms L10-G and L10-A, both as detached specimens and attached to M. edulis.

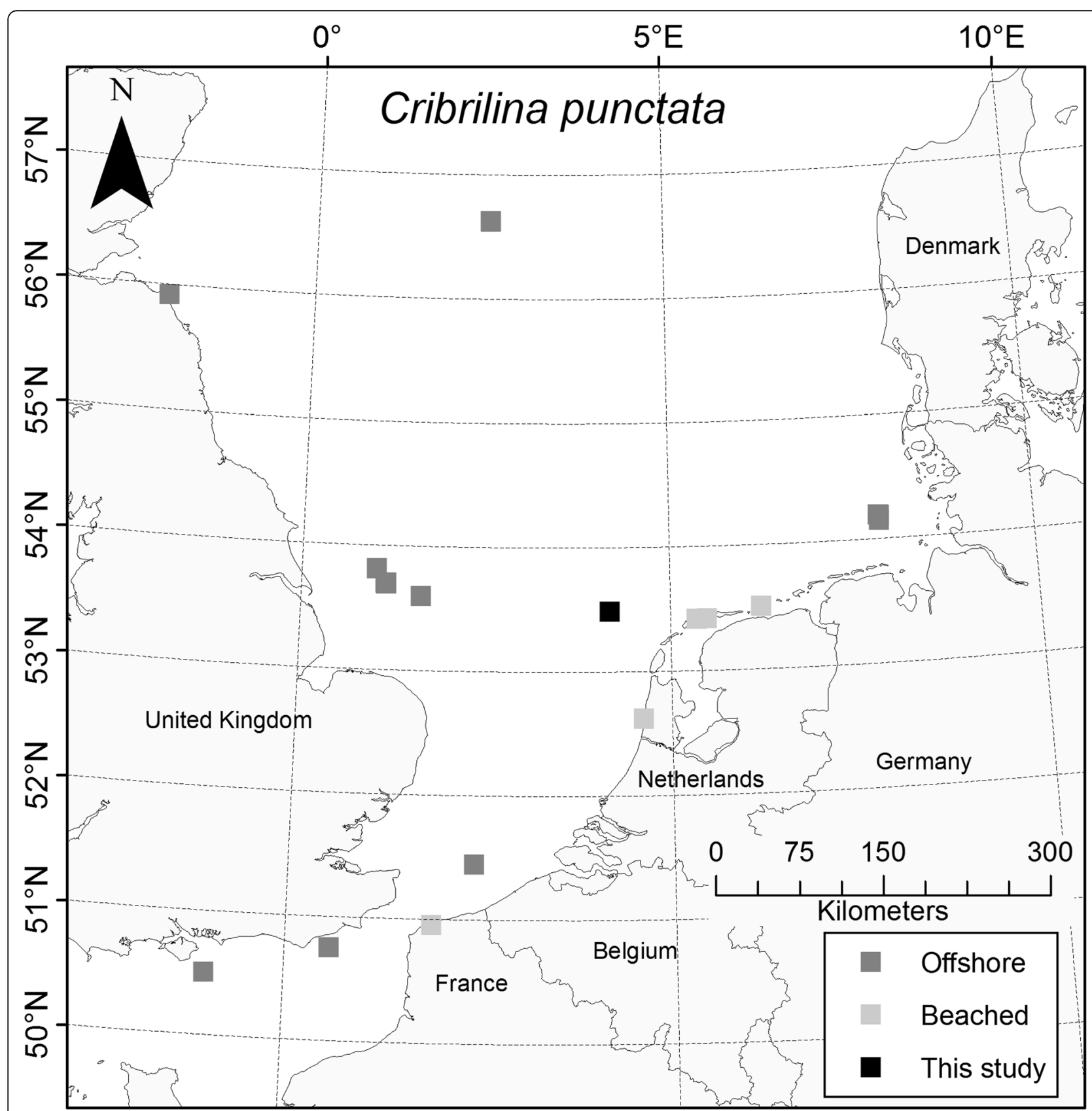

Fig. 2 Observations of Cribrilina punctata in the Netherlands (NMNH 1949; NMR 1992; Glorius et al. 2014), Belgium (De Blauwe 2009), France (VLIZ 2007), Germany (Schultze et al. 1990; De Kluijver 1991; Harms 1993; Kuhlenkamp and Kind 2012) and the United Kingdom (Rees et al. 2005; NRM 2010; Joint Nature Conservation Committee, 2005, Joint Nature Conservation Committee 2004; Marine Biological Association 2010) 


\section{Discussion}

\section{Cribrilina punctata}

Cribrilina punctata is considered a rare species for the southern North Sea with only observations of beached specimens in the Netherlands on bivalve shells (NMNH; NMNH 1949), wood (NMR 1992) and plastic (De Ruijter 2014). Figure 2 shows all observations of C. punctata in the southern North Sea. The authors here now report the first observation of $C$. punctata attached to a fixed object on the Dutch continental shelf.

Cribrilina punctata is easily confused with Collarina balzaci. According to Faasse and De Blauwe (2004) several observations of C. punctata had been wrongly identified in the past leading to the exclusion of C. punctata from the list of Dutch fauna. Moreover, Faasse et al. (2013) excluded specimens found on beached material.

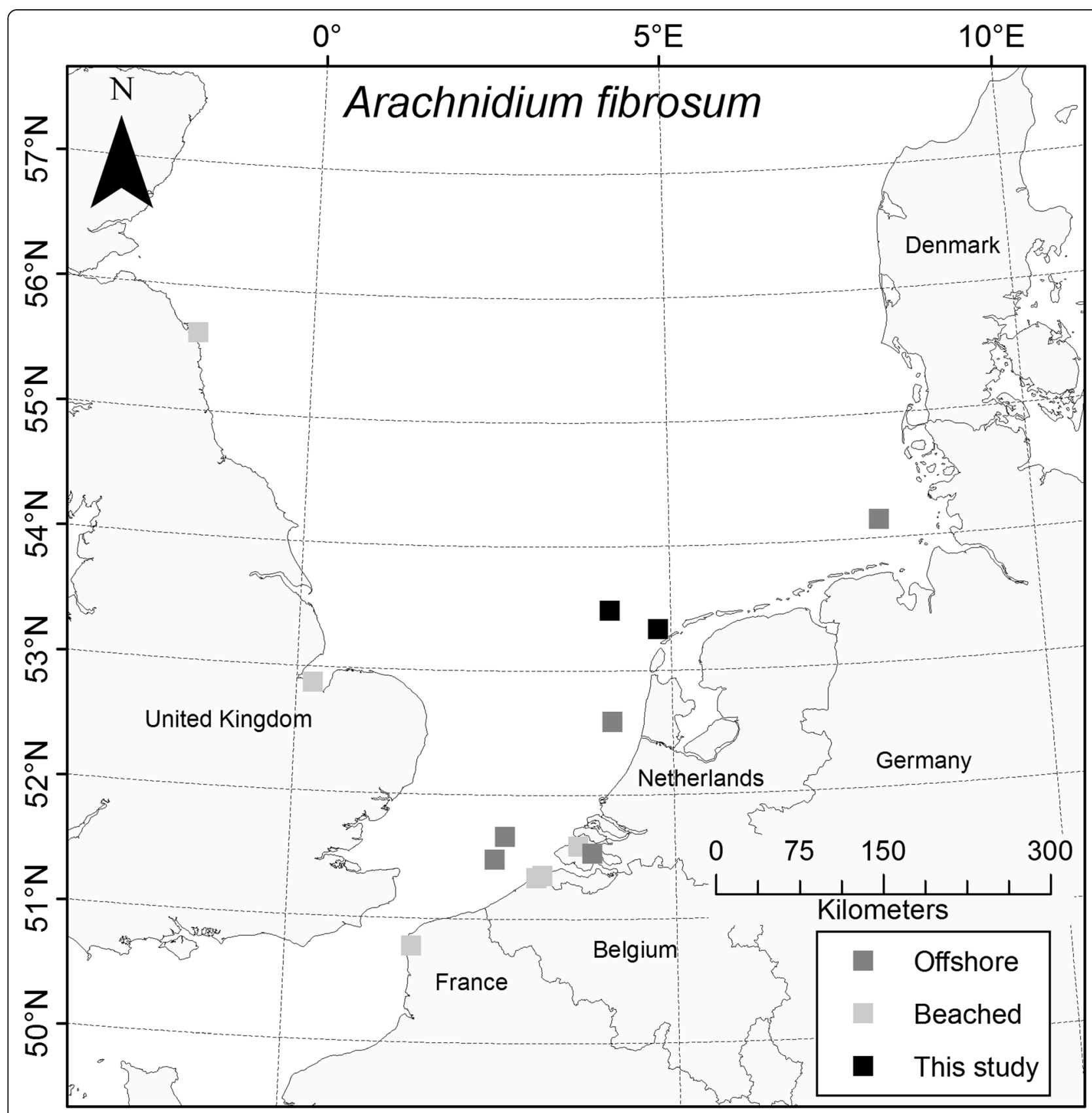

Fig. 3 Observations of Arachnidium fibrosum in the Netherlands (De Blauwe 2009; Vanagt et al. 2013), Belgium (Faasse and De Blauwe 2003; VLIZ 2007; Houziaux et al. 2008; De Blauwe 2009; pers. comm. F. Kerckhof), France (VLIZ 2007) and Germany (Kuhlenkamp and Kind 2012) 


\section{Arachnidium fibrosum}

In the Netherlands Arachnidium fibrosum had been observed before on empty shells in southern coastal waters of the North Sea at 5-10 m depth (De Blauwe 2009) and at the PAWF at 5, 10 and $17 \mathrm{~m}$ depth (Vanagt et al. 2013). This corresponds to our finding of the species at $10 \mathrm{~m}$ depth on Mytilus edulis. However, Vanagt et al. (2013) did not encounter the species on scour protection rocks at the bottom of the wind mill monopiles in contrast to our observation of $A$. fibrosum attached to rocks collected at $21 \mathrm{~m}$ and other observations on rocks from the Belgian Hinder Banks (Houziaux et al. 2008; De Blauwe 2009).

Both beached and offshore observations of $A$. fibrosum from the North Sea are relatively uncommon (Fig. 3) (Hayward 1985; De Blauwe 2009). Indeed, Faasse and De

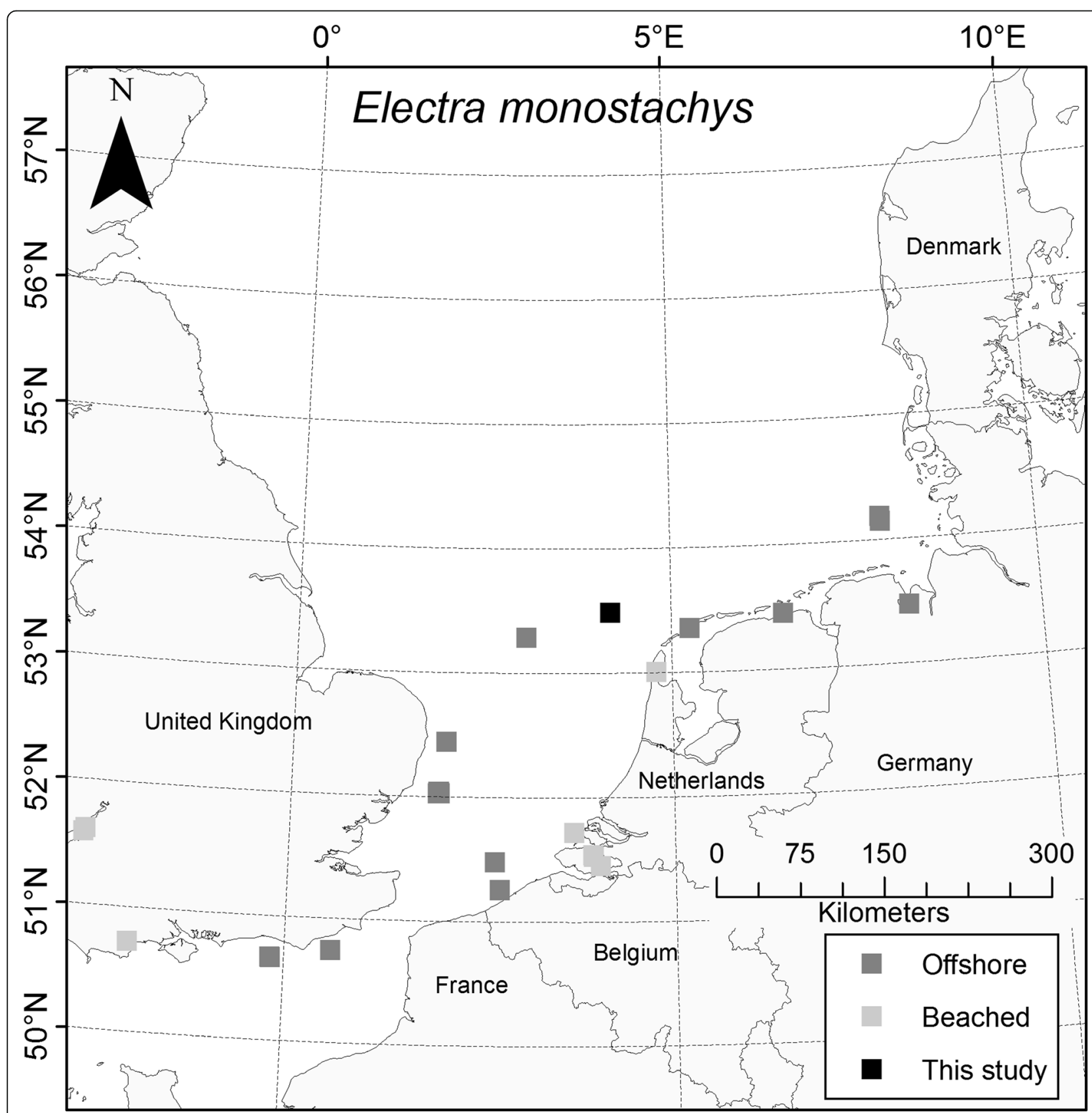

Fig. 4 Observations of Electra monostachys in the Netherlands (Faasse and De Blauwe 2004; De Blauwe 2009), Belgium (VLIZ 2007; De Blauwe 2009), Germany (De Kluijver 1991; Harms 1993; Kittelmann and Harder 2005; Kuhlenkamp and Kind 2012) and United Kingdom (Rees et al. 2005, Cooper et al., 1998; Joint Nature Conservation Committee, 2005; UK National Biodiversity Network: Marine Biological Association 2010) 
Blauwe (2004) emphasize the capability of A. fibrosum zooids to adhere sand and detritus to themselves, making it difficult to observe and identify the species. They suggest this would partly explain the low amount of observations in general. The species often stays unnoticed in preserved material, especially if Jassa spp. (Arthropoda, Malacostraca) tubes are present. Arachnidium fibrosum was extremely common on reef balls deployed in 2013 on the Bligh Bank and studied in 2014 (pers. comm. F. Kerckhof). Research on living material would facilitate the discovery and identification of this species in future research.

\section{Electra monostachys}

Electra monostachys has been observed several times on beached material along the Dutch coast and on shell

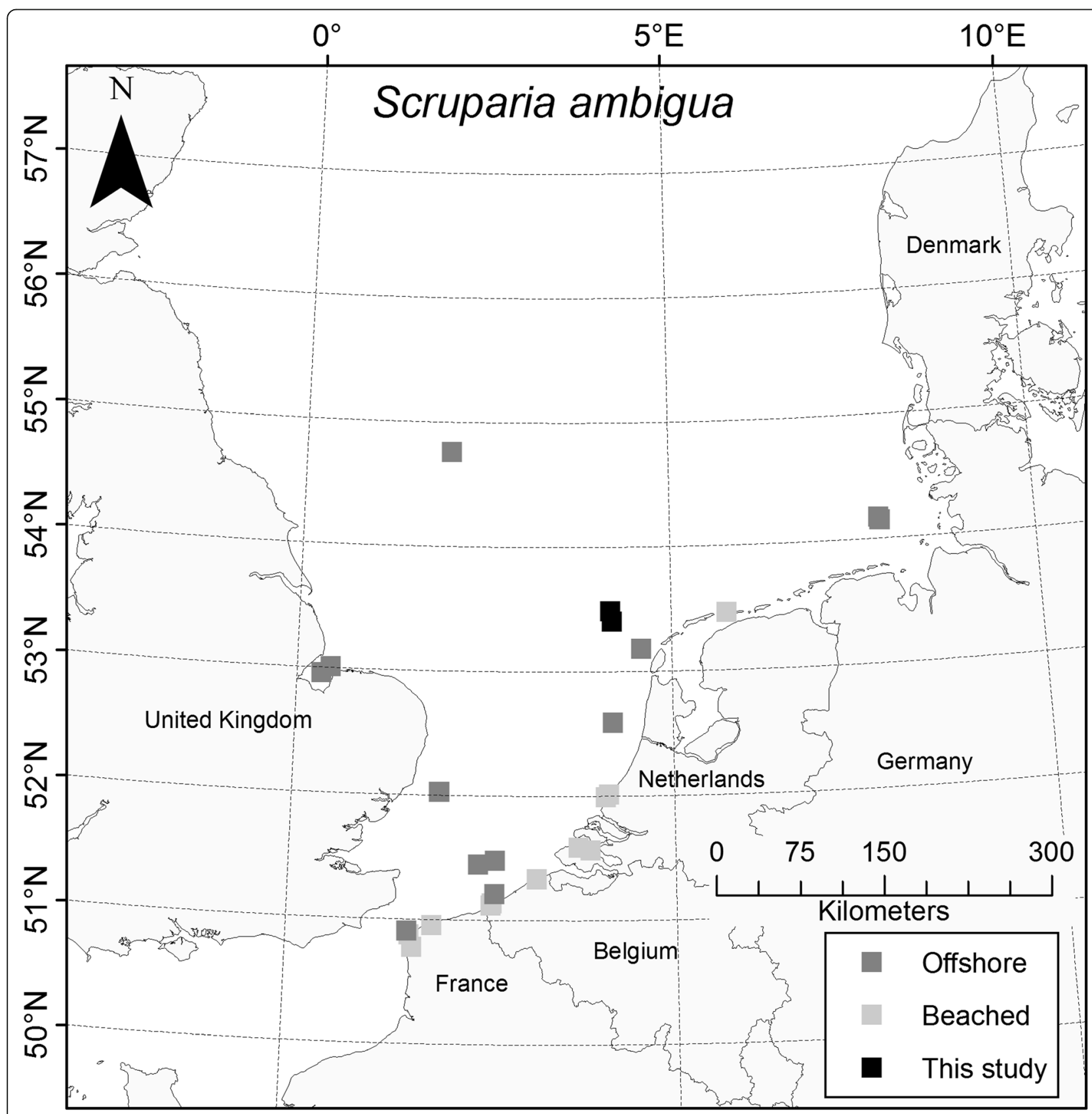

Fig. 5 Observations of Scruparia ambigua in the Netherlands (Faasse and De Blauwe 2004; NMR 2013; Vanagt et al. 2013; Coolen et al. 2015), Belgium (RBINS 1908; Vanhaelen et al. 2006; VLIZ 2007; Houziaux et al. 2008; De Blauwe 2009), France (VLIZ 2007), Germany (Senckenberg 2009; Kuhlenkamp and Kind 2012) and United Kingdom (Joint Nature Conservation Committee, 2005; UK National Biodiversity Network: Marine Biological Association 2010) 
banks around the Dutch Wadden Sea Islands (De Blauwe 2009). Observations in the entire North Sea reported both a more northern and southern distribution than our specimen (Fig. 4).

\section{Scruparia ambigua}

Few observations of Scruparia ambigua exist for the Netherlands, and it is considered rare for the southern
North Sea (De Blauwe 2009). In the Netherlands the most recent findings were at the PAWF (Vanagt et al. 2013) and the Borkum Reef Grounds (Coolen et al. 2015). In the current study the species was encountered at two platforms between 5 and $10 \mathrm{~m}$ depth, though Vanagt et al. (2013) observed the species several times at a slightly greater depth range $(2-17 \mathrm{~m})$. Several beached specimens have been reported as well (Fig. 5).

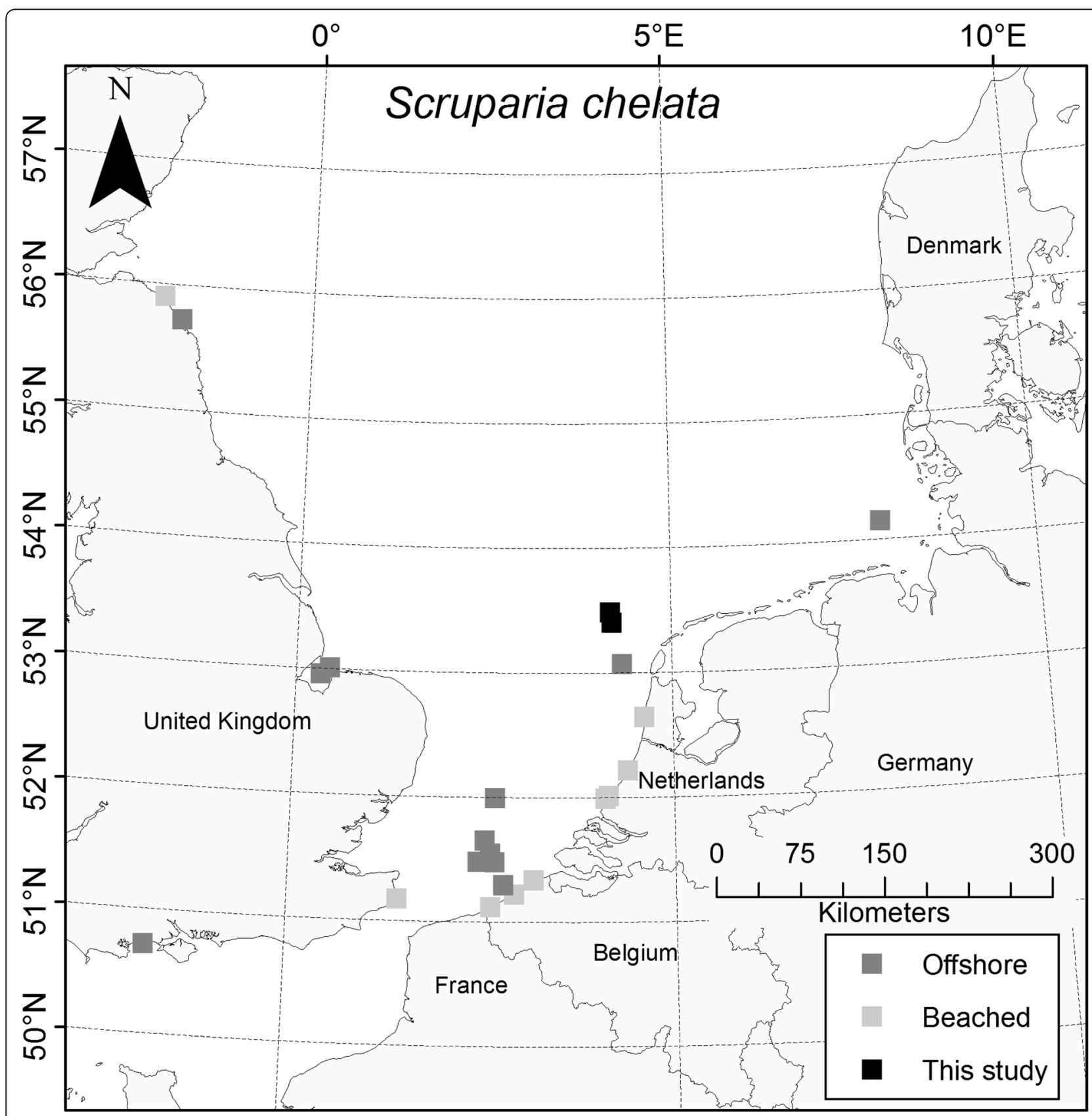

Fig. 6 Observations of Scruparia chelata in the Netherlands (Verkuil 1998; De Ruijter 2006; Lengkeek et al. 2013b; NMR 2013), Belgium (De Blauwe 2000, 2009; Vanhaelen et al. 2006; VLIZ 2007; Houziaux et al. 2008; Zintzen and Massin 2010), Germany (Harms 1993; Kuhlenkamp and Kind 2012) and United Kingdom (De Kluijver 1993; Joint Nature Conservation Committee, 2005; Marine Conservation Society, 2010) 


\section{Scruparia chelata}

Scruparia chelata has only recently been discovered in the Netherlands on a shipwreck $(24 \mathrm{~km}$ off the coast of Texel) by Lengkeek et al. (2013b) who investigated ten shipwrecks on the Dutch continental shelf. Other observations of the species across the North Sea have been reported from more northerly and southerly locations than the Dutch specimens (Fig. 6). De Blauwe (2009) considered S. chelata as rare for the southern North Sea, although beached specimens, most likely originating from the English Channel, are common.

\section{Absence of Fenestrulina delicia}

Fenestrulina delicia Winston, Hayward and Craig, 2000 is an invasive species that has been present in European waters since 2002 or earlier (Wasson and De Blauwe 2014). It was reported in the Shetlands, in Northern Ireland, on the west coast of Scotland, on both sides of the English channel, in the North Sea along the coast of Belgium, the Netherlands and Germany as far as Helgoland and along the west coast of the UK (De Blauwe et al. 2014; Wasson and De Blauwe 2014). A majority of the locations inhabited by $F$. delicia are wind farms and gas platforms. It is therefore noteworthy that $F$. delicia was absent in our samples.

\section{More species to be expected}

In this study six species were encountered mainly on $M$. edulis shells attached to the platform foundation while four species were found exclusively on the scour protection rocks at the seafloor. This indicates differences in preferred substrate and environmental conditions between bryozoan species. Some hard substrate areas on the Dutch continental shelf, such as the Texel Rough, remain uninvestigated. Moreover, bryozoan species known from empty shells on sandbanks on the Belgian and British continental shelf can be expected to be discovered also on Dutch sandbanks nearby (Faasse et al. 2013).

\section{Acknowledgements}

This work was funded through the Wageningen UR TripleP@Sea Innovation programme (KB-14-007) and supported by GDF SUEZ E\&P Nederland B.V., the Nederlandse Aardolie Maatschappij B.V., Wintershall Holding GmbH and EBN B.V. We are grateful to the staff of GDF SUEZ and the Bluestream dive team for their help during diving and sampling. The authors thank Naturalis Biodiversity Centre and the Natural History Museum Rotterdam for their cooperation in revising their specimens. We thank Britta Kind for her valuable comments on the manuscript and for providing data of several species records.

\section{Authors' contribuions}

JCo designed the study, carried out the sampling and created the maps. JCo, $\mathrm{EB}$ and $J \mathrm{~L}$ handled the samples in the lab and prepared them for taxonomic determination. EB, BW, JCu, HB and JL performed the taxonomic determination. $E B$ collected data on observations of species at other locations and drafted the manuscript. All authors read and approved the final manuscript.

\section{Competing interests}

The authors declare that they have no competing interests.

\section{Author details}

${ }^{1}$ Current address: Centre for Ocean Life, National Institute of Aquatic Resources (DTU Aqua), Technical University of Denmark, Jægersborg Allé 1, 2920 Charlottenlund, Denmark. Wageningen University \& Research, Chair Group of Aquatic Ecology and Water Quality Management, PO Box 47, 6700 AA Wageningen, The Netherlands. ${ }^{3}$ Maritime Department, Wageningen Marine Reseach, PO Box 57, 1780 AB Den Helder, The Netherlands. ${ }^{4}$ Department of Invertebrates, Royal Belgian Institute of Natural Sciences, Vautierstraat 29, 1000 Brussels, Belgium. ${ }^{5}$ Van Hall Larenstein, Integrated Coastal Zone Management, 8934 CJ Leeuwarden, The Netherlands.

Received: 13 June 2016 Accepted: 14 July 2016

Published online: 11 October 2016

\section{References}

Coolen JWP, Bos OG, Glorius S, Lengkeek W, Cuperus J, Van der Weide BE, Agüera A. Reefs, sand and reef-like sand: a comparison of the benthic biodiversity of habitats in the Dutch Borkum Reef Grounds. J Sea Res. 2015; 103:84-92.

Cooper KM, Boyd SE, Rees HL. Cross Sands broadscale survey 1998, Centre for Environment, Fisheries and Aquaculture. Essex, UK: Burnham laboratory; 1998. De Blauwe H. Riemwiervoetjes en hun begroeiing. De Strandvlo. 2000;20:89-94.

De Blauwe H. Mosdiertjes van de zuidelijke bocht van de Noordzee Determinatiewerk voor België en Nederland. Oostende: Vlaams Instituut voor de Zee; 2009.

De Blauwe H, Kind B, Kuhlenkamp R, Cuperus J, Van der Weide B, Kerckhof F. Recent observations of the introduced Fenestrulina delicia Winston, Hayward \& Craig, 2000 (Bryozoa) in Western Europe. Studi Trentini di Scienze Naturali. 2014:94:45-51.

De Kluijver MJ. Sublittoral hard substrate communities off Helgoland. Helgoländer Meeresuntersuchungen. 1991;45:317-44.

De Kluijver MJ. Sublittoral hard-substratum communities off Orkney and St Abbs (Scotland). J Mar Biol Assoc UK. 1993;73:733-54.

De Ruijter R. Naar het strand, of toch maar niet? Het Zeepaard. 2006;66:29-30.

De Ruijter R. Cs-verslag. Het Zeepaard. 2014;74:38-45.

Faasse M, De Blauwe H. Het mosdiertje Arachnidium fibrosum Hincks, 1880 nieuw voor België en Nederland. De Strandvlo. 2003:23:47-9.

Faasse M, De Blauwe H. Faunistisch overzicht van de mariene mosdiertjes van Nederland (Bryozoa: Stenolaemata, Gymnolaemata). Nederlandse Faunistische Mededelingen. 2004;21:17-54.

Faasse M, Van Moorsel GWNM, Tempelman D. Moss animals of the Dutch part of the North Sea and coastal waters of the Netherlands (Bryozoa). Nederlandse Faunistische Mededelingen. 2013:41:1-14.

Glorius ST, Wijnhoven S, Kaag NHBM. Benthos community composition along pipeline trajectory A6-A-Ravn. An environmental baseline study. Den Helder: IMARES Wageningen UR; 2014. p. 49. Report Number C116.14.

Harms J. Check list of species (algal, invertebrates and vertebrates) found in the vicinity of the island of Helgoland (North Sea, German Bight) - a review of recent records. Helgoländer Meeresuntersuchungen. 1993;47:1-34.

Hayward PJ. In: Brill EJ, Backhuys W, editors. Ctenostome Bryozoans. Synopsis of the British Fauna (new series). London: The Linnean Society of London; 1985.

Hayward P, Ryland J. Cheilostomatous Bryozoa: 1. Aeteoidea - Cribrilinoidea: notes for the identification of British species. 2nd ed. Shrewsbury: Field Studies Council; 1998.

Hayward P, Ryland J. Cheilostomatous Bryzoa: 2. Hippothooidea - Celleporoidea: notes for the identification of British species. 2nd ed. Shrewsbury: Field Studies Council; 1999

Houziaux JS, Kerckhof F, Degrendele K, Roche M, Norro A. The Hinder banks: yet an important region for the Belgian marine biodiversity? Brussels: Belgian Science Policy; 2008. p. 249. Report EV/45.

Joint Nature Conservation Committee. Marine benthic dataset (version 1) commissioned by UKOOA. 2004. NBN Gateway. https://data.nbn.org.uk/ Datasets/GA000182 [Accessed at 18 Aug 2015].

Joint Nature Conservation Committee. Marine Nature Conservation Review (MNCR) and associated benthic marine data held and managed by JNCC. 2005. NBN Gateway. https://data.nbn.org.uk/Datasets/GA000190 [Accessed at 26 Jan 2016].

Kittelmann S, Harder T. Species- and site-specific bacterial communities associated with four encrusting bryozoans from the North Sea, Germany. J Exp Mar Biol Ecol. 2005;327:201-9. 
Kuhlenkamp R, Kind B. Makrozoobenthos Monitoring Helgoland 2011, Maßnahme im Rahmen der WRRL. Report of the State Agency for Agriculture. Germany: Nature and Rural Areas (LLUR) of Schleswig-Holstein; 2012. p. 55

Lengkeek W, Coolen JWP, Gittenberger A, Schrieken N. Ecological relevance of shipwrecks in the North Sea. Nederlandse Faunistische Mededelingen. 2013a; 40:49-58.

Lengkeek W, Didderen K, Dorenbosch M, Bouma S, Waardenburg H. Bureau Waardenburg bv and Stichting De Noordzee, rapport nr. 13-226, 76 ppx. Culemborg, Nethelands: Bureau Waardenburg bv and Stichting De Noordzee, rapport nr; 2013b. p. 13.

Lindeboom HJ, Kouwenhoven HJ, Bergman MJN, Bouma S, Brasseur S, Fijn RC, De Haan D, Dirksen S, Van Hal R, Hille Ris Lambers R, Ter Hofstede R, Krijgsveld KL, Leopold M, Scheidat M. Short-term ecological effects of an offshore wind farm in the Dutch coastal zone; a compilation. Environ Res Lett. 2011;6:1-13.

Marine Conservation Society. Seasearch Marine Surveys. 2010. NBN Gateway. https://data.nbn.org.uk/Organisations/53 [Accessed at 18 Aug 2015].

NMNH. ZMA.BRYO.95 Cribrilina punctata (Hassell, 1841). the Netherlands: National Museum of Natural History; 1949.

NMNH. ZMA.BRYO.2073 Cribrilina punctata (Hassell, 1841). the Netherlands: National Museum of Natural History.

NMR. NMR992800000029 Cribrilina punctata (Hassell, 1841). the Netherlands: Natural History Museum Rotterdam; 1992.

NMR. Natural history museum Rotterdam, the Netherlands - Invertebrata miscellaneous Collection. 2013. http://www.gbif.org/dataset/7bb2d451-5ffa4d58-bc7f-19ea7aecb201 [Accessed at 18 Aug 2015].

NRM. Invertebrates Collection of the Swedish Museum of Natural History. 2010. http://www.gbiforg/dataset/56aa0680-0c60-11dd-84cd-b8a03c50a862 [Accessed at 18 Aug 2015].

RBINS. G5004 Scruparia ambigua (d'Orbigny, 1841). Brussels, Belgium: Royal Belgian Institute of Natural Sciences; 1908.

Rees HL, Pendle MA, Waldock R, Limpenny D, Boyd SE. A comparison of benthic biodiversity in the North Sea, English Channel and Celtic Seas - Epifauna, Centre for Environment, Fisheries and Aquaculture Science. Essex, UK: Burnham Laboratory; 2005.

Schrieken N, Gittenberger A, Coolen JWP, Lengkeek W. Marine fauna of hard substrata of the Cleaver Bank and Dogger Bank. Nederlandse Faunistische Mededelingen. 2013:41:69-78.

Schultze K, Janke K, Krüß A, Weidemann W. The macrofauna and macroflora associated with Laminaria digitata and L. hyperborea at the island of Helgoland (German Bight, North Sea). Helgoländer Meeresuntersuchungen. 1990:44:39-51.

Senckenberg. Collection Bryozoa SMF. 2009. http://www.gbif.org/dataset/ 966c9070-f762-11e1-a439-00145eb45e9a [Accessed at 18 Aug 2015].

UK National Biodiversity Network: Marine Biological Association. Marine Biological Association - Marine survey data (Professional) held by MarLIN. 2010. http:// www.gbif.org/dataset/cc2031d1-395d-4052-8ce1-796a08c3dbf2 [Accessed at 18 Aug 2015].

Van Buuren J. Ecological survey of a North Sea gas leak. Mar Pollut Bull. 1984;15: 305-7.

Van der Stap T, Coolen JWP, Lindeboom HJ. Marine fouling assemblages on Offshore Gas Platforms in the Dutch part of the North Sea: Effects of depth and distance from shore on biodiversity. PLoS One. 2015;11:e0146324. doi:10. 1371/journal.pone.0146324.

Van Moorsel GWNM. Ecologie van de Klaverbank. BiotaSurvey 2002. Doorn: Ecosub; 2003. p. 157.

Vanagt T, Van de Moortel L, Faasse M. Development of hard substrate fauna in the Princess Amalia Wind Farm. Oostende: eCOAST; 2013. p. 42. report 2011036.

Vanhaelen M, Jonckheere I, De Blauwe H. Grote wierenstranding aan de Belgische Westkust tijdens de zomer van 2005. De Strandvlo. 2006;26:5-11. Verkuil J. CS-verslag. Het Zeepaard. 1998;58:150-7.

VLIZ. Taxonomic Information Sytem for the Belgian coastal area (EurOBIS). 2007. http://www.gbif.org/dataset/83bb72ac-f762-11e1-a439-00145eb45e9a [Accessed at 18 Aug 2015].

Wasson B, De Blauwe H. Two new records of cheilostome Bryozoa from British waters. Marine Biodiversity Records. 2014;7:1-4.

WoRMS Editorial Board. World register of marine species. 2015.

Zintzen V, Massin C. Artificial hard substrata from the Belgian part of the North Sea and their influence on the distributional range of species. Belg J Zool. 2010;140:20-9.

\section{Submit your next manuscript to BioMed Central and we will help you at every step:}

- We accept pre-submission inquiries

- Our selector tool helps you to find the most relevant journal

- We provide round the clock customer support

- Convenient online submission

- Thorough peer review

- Inclusion in PubMed and all major indexing services

- Maximum visibility for your research

Submit your manuscript at www.biomedcentral.com/submit
Biomed Central 